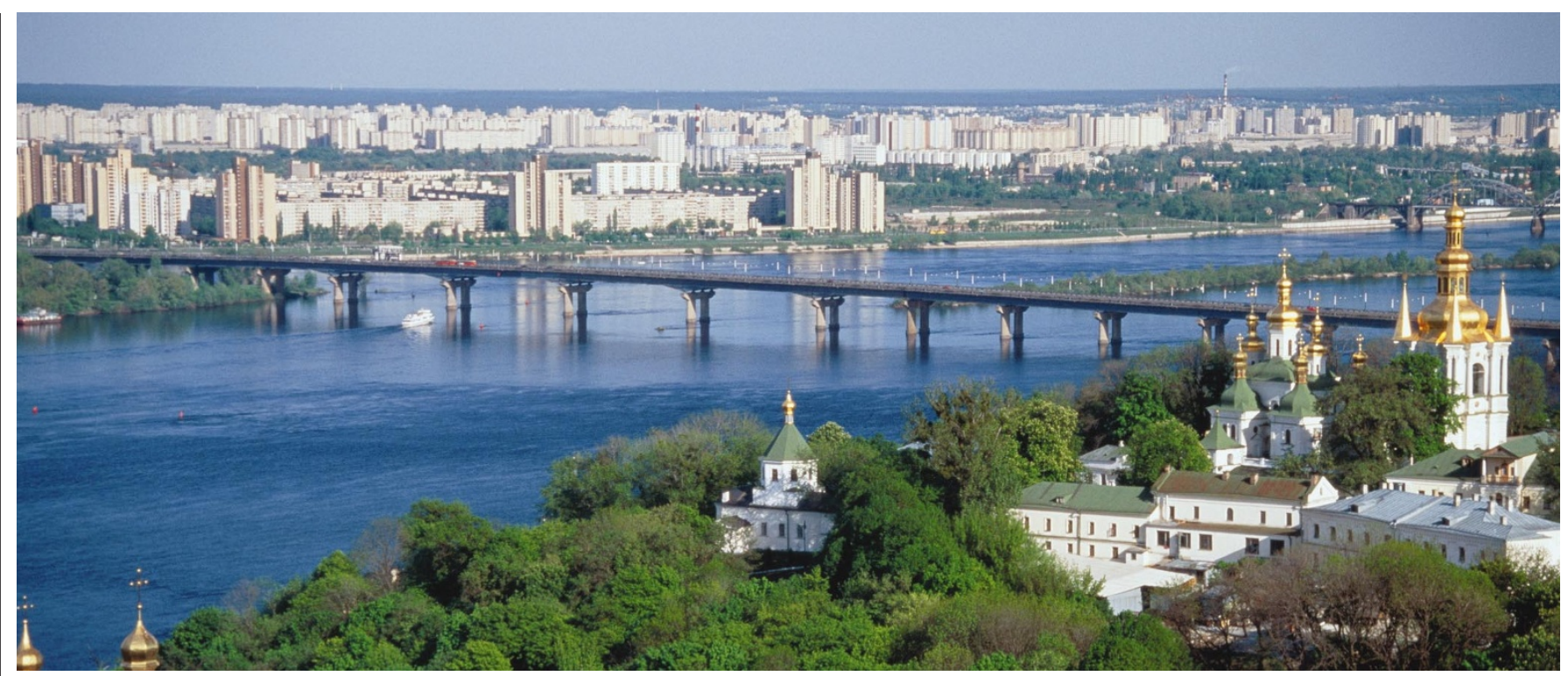

\title{
DIY, Kiev style
}

\section{Many Ukrainian research institutes went to the wall when the Soviet Union collapsed. Quirin Schiermeier finds out how home-grown talent - and home-made equipment - have helped one centre to buck the trend.}

$\mathrm{T}$ he Soviet-era tower block that dominates Bogomoletz Street is a prestigious address in the Ukrainian capital of Kiev. US investment bankers occupy one office. From another, the television channel OTV broadcasts music videos to Ukraine's youth. And at the top of the building, a spacious, well-equipped animal house is home to hundreds of mice, rabbits and guinea pigs.

The animal facilities belong to the A. A. Bogomoletz Institute of Physiology, a research centre whose reputation has survived the turmoil that followed the collapse of the Soviet Union at the start of 1990s. Once the breadbasket of the communist

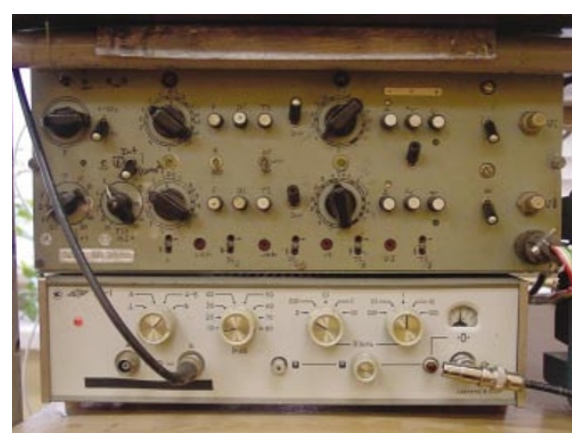

Self-sufficient: building their own equipment has allowed Bogomoletz researchers to keep working. superpower, Ukraine was left with just crumbs - and scientists suffered alongside everyone else. A quarter of the Soviet Union's immense research resources once flowed into Ukraine. Now, annual government funding for the country's 150,000 researchers and engineers has dipped below US $\$ 100$ million - a fraction of western European science budgets.

Despite this, the Bogomoletz Institute continues to produce quality research work that neuroscientist Erwin Neher, jointwinner of the 1991 Nobel Prize in Physiology or Medicine, describes as "world-class".

\section{Channel vision}

The institute has an impressive history. Located in the heart of Kiev, it was created in 1953 when the Ukrainian Academy of Sciences' Institute of Clinical Physiology was merged with the Institute of Experimental Biology and Pathology, part of the Ukrainian health ministry. Thanks largely to the work of Platon Kostyuk, who joined the institute in 1958 and today serves as its director at the age of 78, the Bogomoletz became the Soviet Union's premier centre for neurophysiology.

During a 1961 sabbatical at John Eccles' laboratory at the Australian National Univer-

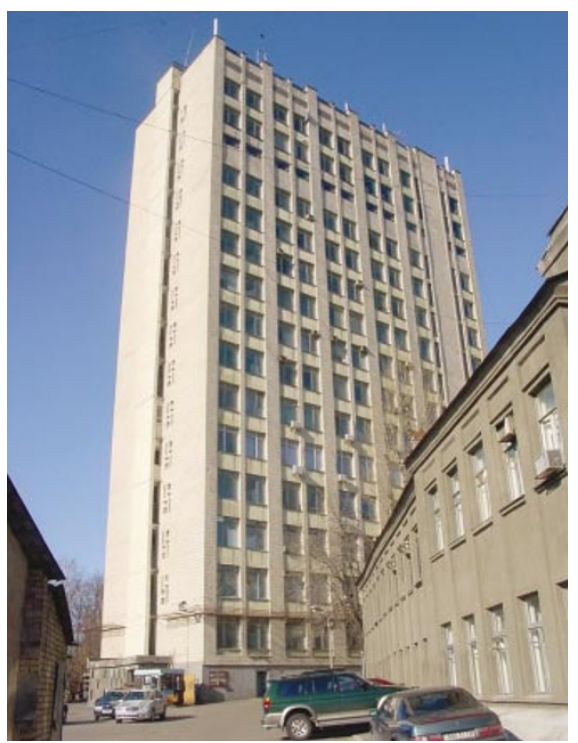

High riser: despite financial worries, Kiev's

Bogomoletz Institute (above) is world-renowned.

sity in Canberra, Kostyuk learnt how to use very fine electrodes to probe the workings of brain cells. He introduced the technique to the Bogomoletz Institute on his return - the first time the procedure had been used in the Soviet Union. Subsequently, Kostyuk and his colleagues made big contributions to our understanding of ion channels in nerve cell membranes. They were the first, for example, to show that ion channels can be separated into low- and high-voltage types. By the time Kostyuk became director in 1966, the institute had developed an international reputation.

Kostyuk and his colleagues went on to develop an early variant of the patch-clamp technique. This method, which revolutionized cell physiology, involves monitoring the opening and closing of ion channels by placing a fine pipette filled with a conducting solution over a patch of membrane. The technique was eventually perfected in the late 1970s by Neher and Bert Sakmann at the Max 
Planck Institute for Biophysical Chemistry in Göttingen, Germany, for which the pair earned their Nobel.

When the Soviet Union unravelled, it became clear that the Bogomoletz Institute faced a difficult future. Withdrawal of Soviet funding has devastated Ukraine's research base, and like most of the country's 1,500 research centres, the Bogomoletz experienced hardship. But an influx of foreign funding and a knack for building their own equipment have allowed its best researchers to remain internationally competitive.

\section{Speech therapy}

The institute's education programme, created by Kostyuk, is at the heart of its success. Would-be brain researchers undergo a tough three-year training in mathematics, physics and chemistry, conducted in both English and Russian, before they join a group at the Bogomoletz to specialize in physiology. In the Soviet era, this training was done at the Moscow Institute of Physics and Technology; today, the students go to the Physical Engineering Centre in Kiev.

At weekly seminars, Kostyuk keeps alive the relaxed international flair and scientific openness he captured in Australia. Research students gather each Friday in a draughty lecture hall to discuss their work with Kostyuk and visiting academics — talks that Kostyuk insists are held in English.

But some researchers inevitably chose to move on. Olga Garaschuk left the institute in 1992 to take up a position at the LudwigMaximilians University of Munich. She says her work on calcium signalling in developing brains would be impossible without the advanced optical imaging technology that is available in her lab. The four microscopes in Garaschuk's lab each cost at least $\$ 200,000$ far more than the Bogomoletz can afford.

But a lack of resources does not always prevent Bogomoletz researchers from getting the equipment they need. Nickolai Veselovsky uses microelectrode techniques to study how calcium ions trigger brain cells to release chemical signals. His group owns

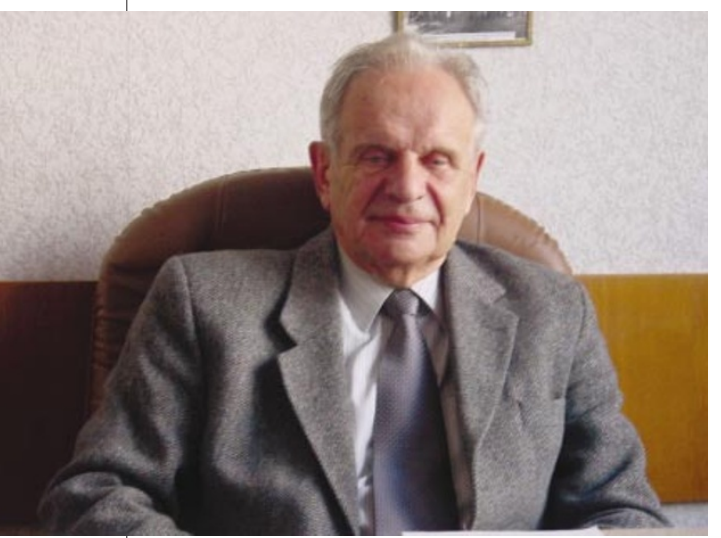

Father figure: Platon Kostyuk's scientific vision has helped to maintain the institute's success. some modern purpose-built, Germanmade microscopes, each of which cost $\$ 20,000$. But other equipment, such as the micromanipulators used to position the electrodes, has been built in-house.

Some researchers have even cannibalized Soviet weapons. Elena Lukyanetz, a young biophysicist, images the intracellular ions that prompt brain cells to release neurotransmitters - chemical signals used to communicate between nerve cells. She uses a device built from optical equipment salvaged from a dismantled SS-20 missile.

Parts of the institute may have an air of do-it-yourself, but Veselovsky claims that his equipment allows state-of-the-art research on nerve transmission - a view shared by Neher, who coordinates some projects at the institute under a UNESCO-funded scheme. "After all," says Veselovsky, "constructing your own devices has a strong tradition in classic physiology."

\section{Joint effort}

The institute also exploits the connections gained when its researchers move to foreign centres. Around 130 former Bogomoletz scientists are working in European and North American institutes. Alexej Verkhratsky, currently at the University of Manchester, UK, is one. He is collaborating with Veselovsky, one of seven Bogomoletz researchers who between them have received $\$ 1$ million from the Wellcome Trust, Britain's leading biomedical research charity.

Such links are helping the Bogomoletz through difficult times, but the institute has long been outward-looking. It has, for example, hosted a regular international meeting, organized in conjunction with physiological societies in Spain, Italy, Germany, Britain and the United States, since the 1970s. "It was our international reputation which helped us survive when we were suddenly forced to look for money ourselves," says Kostyuk. Today, grants from bodies such as the NATO Science Programme, which supports scientific collaborations between countries in the Middle East, eastern Europe and NATO member states, are an elixir of life.

Lukyanetz's group has, for example, recently received an $\$ 80,000$ grant from INTAS, an independent body supported by the European Union to promote East-West scientific cooperation. She is using the funds to study how packets of neurotransmitters are moved around within cells, and how proteins found at the junctions between cells influence this movement. The collaborative project, coordinated by Neher, involves groups from Germany and Britain.

Kostyuk has also found other means of bringing money into the institute, such as the subletting schemes that have brought OTV and investment bankers into the building. Thanks to its privileged location in the city centre, the institute can charge rents equal to

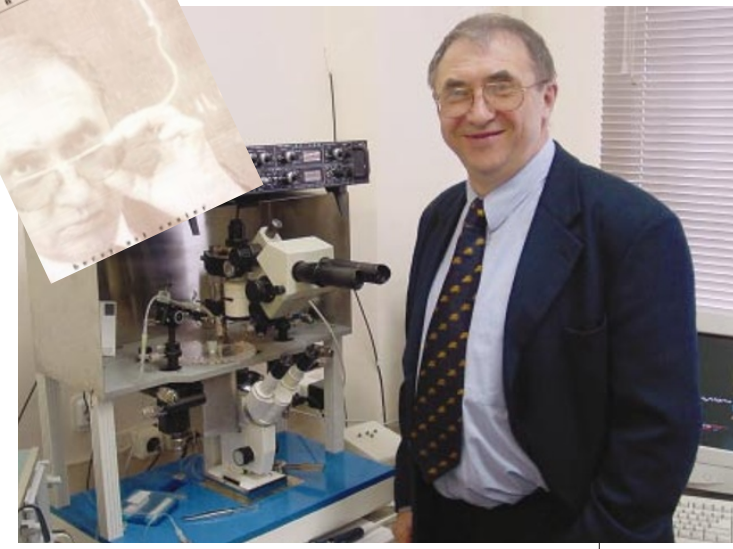

With his book finished, Oleg Krishtal hopes to market his patch-clamp robot for screening drugs.

those of other European capitals.

Contract research for western pharmaceutical companies is also becoming a substantial source of additional income. "We are able to deliver complete pharmacological profiles of substances within only three days," says Oleg Krishtal, deputy director of the institute and head of cellular membrane research. Some researchers familiar with the Bogomoletz say that this contract work includes animal experiments. Kostyuk declines to comment, but concedes that it is much easier to get permissions under Ukraine's relaxed animalprotection laws than in the West.

The institute also hopes to start its own companies. Krishtal is planning to use a homemade patch-clamp robot to examine the pharmaceutical potential of toxins in the venoms of cone shells, a type of mollusc. Some of these toxins inhibit one of the major pain receptors found in neurons. He hopes to launch a start-up company in collaboration with Andrew Miller, a director of the new Genetic Therapies Centre at Imperial College, London, and Leonid Moroz, a neuroscientist at the University of Florida in St Augustine.

Staff at the Bogomoletz Institute are glad that Krishtal is once again dedicating all of his energy to research. Described by Neher as a visionary scientist, he has recently finished his book To The Singing of Birds, a poetic and philosophical examination of consciousness and evolution that has been widely acclaimed in the Russian and Ukrainian media. No date has been set for Kostyuk's retirement, but many researchers at the Bogomoletz hope that Krishtal will take over when he does finally step down.

Whoever succeeds Kostyuk will have a tough act to follow. Ukraine's politics and economy may be more settled than in the immediate aftermath of the Soviet collapse, but the institute's funding is still far from certain. Its researchers are proud to work in eastern Europe's most prestigious neuroscience centre. But Kostyuk's successor will have to work hard if they are to keep their crown.

Quirin Schiermeier is Nature's German correspondent.

www.biph.kiev.ua 